\title{
Aloe vera Leaf Anti Inflamation's Activity Speeds Up the Healing Proccess of Oral Mucosa Ulceration
}

\author{
Agoeng Tjahajani, Widurini \\ Departement of Oral Biology, Faculty of Dentistry, Universitas Indonesia, Jakarta 10430, Indonesia \\ Correspondence e-mail to: agoengtjahajani@yahoo.co.id
}

\begin{abstract}
In Indonesia, Aloe vera leaf is one of the herbal plants used as traditional medicines in treating many health problems. Previous work showed that $25 \%$ of inner layer Aloe vera leaf extract was effective as antiinflammatory on the oral mucous of Wistar rats. Objective: The aim of this study was to examine the lowest concentration of whole leaf Aloe vera extract that could accelerate healing process of ulceration on rats. Methods: Sixty inbreeding Spraque Dawley rats was exposed to solution of Hydrogen Peroxide 10\% during three days to induced inflammation on the labial mucous inferior of rats. During the next three days, on the same area of control group were topically applied solution of Natrium Chloride $0.9 \%$; while in the treatment group were topically applied $6.25 \% ; 12.5 \% ; 25 \%$ of whole leaf of Aloe vera extract for $3 \times 5$ minutes with 90 minutes intervals. On the fourth day, five rats in each group were sacrificed; and the same treatment was done on others groups. On the sixth day, five rats of each group were sacrificed; and the same treatment was done on the rest group up to seven days. On the eighth days, the rest groups were sacrificed. Microscopic slides were done. Results: Microscopic slides were analyzed under light microscope and scored. Statistical analysis with Mann-Whitney test showed significant differences between control and treatment group $(p \leq 0.05)$. Conclusion: Application of $6.25 \%$ whole leaf Aloe vera extract was the lowest and the most effective concentration in accelerating the healing process of oral mucous ulceration on rats.
\end{abstract}

\begin{abstract}
ABSTRAK
Aktifitas anti-inflamasi ekstrak daun aloe vera mempercepat proses penyembuhan ulserasi mukosa mulut. Di Indonesia, daun Aloe vera merupakan tanaman herbal yang digunakan sebagai obat tradisional untuk mengobati berbagai penyakit. Penelitian terdahulu menyatakan bahwa $25 \%$ bagian daging Aloe vera ekstrak efektif sebagai antiinflamasi pada mukosa mulut tikus Spraque Dawley. Tujuan: Studi in bertujuan untuk menganalisis konsentrasi terendah ekstrak daun Aloe vera terhadap penyembuhan ulkus mukosa mulut tikus. Metode: 60 ekor tikus diberikan cairan $\mathrm{H}_{2} \mathrm{O}_{2} \quad 10 \%$ pada mukosa labial bibir bawah selama 3 hari untuk merangsang terjadinya ulkus. Selama 3 hari berikutnya, pada kelompok kontrol di area yang sama, dilakukan aplikasi cairan Natrium Chlorida 0,9\% selama 3x5 menit, dengan interval 90 menit. Sedang pada kelompok perlakuan, dilakukan aplikasi 6,25\%; 12,5\%; 25\% ekstrak daun Aloe vera selama 3x5 menit dengan interval 90 menit. Pada hari keempat, 5 tikus dari tiap kelompok dimatikan; sedangkan pada kedua kelompok dilakukan aplikasi yang sama. Pada hari keenam, 5 tikus dari tiap kelompok dimatikan; perlakukan yang sama dilanjutkan pada sisa tikus pada kedua kelompok sampai hari ketujuh. Pada hari kedelapan, semua tikus yang ada dimatikan. Spesimen dikirim ke Departemen Patologi untuk dibuat sediaan mikroskopik dengan pulasan HE. Hasil: Gambaran mikroskopik dianalisis dengan mikroskop cahaya dan dilakukan skoring. Analisa statistik dengan Mann-Whitney test menunjukkan adanya perbedaan bermakna antara kelompok kontrol dan kelompok perlakukan, pada $p \leq 0,05$. Simpulan: Aplikasi 6,25\% esktrak daun Aloe vera merupakan konsentrasi terendah dan efektif dalam mempercepat proses penyembuhan ulkus mukosa mulut tikus.
\end{abstract}

Key words: whole extract, aloe vera, healing process, oral mucosal ulcer 


\section{PENDAHULUAN}

Sejarah mencatat bahwa Aloe vera telah banyak digunakan di negara-negara seperti Mesir, Yunani, Afrika Selatan, India, Cina, Meksiko dan Jepang. Di negara-negara tersebut, Aloe vera digunakan sebagai bahan obat sejak beberapa ribu tahun yang lalu; untuk mengobati luka bakar, rambut rontok, infeksi kulit, peradangan sinus, dan rasa nyeri pada saluran cerna. ${ }^{1,2}$ Secara kimiawi, Aloe vera mengandung beberapa zat seperti auksin, gibberrelin, antrakuinon, vitamin A, C, E. Beberapa peneliti terdahulu telah membuktikan bahwa Aloe vera berkhasiat sebagai antiinflamasi, anticacing, antipiretik, antijamur, antioksidan, antiseptik, antimikroba, serta antivirus. ${ }^{1-3}$ Aloe vera adalah tanaman kaktus yang termasuk family Liliaceae. Di seluruh dunia, diperkirakan Aloe vera mencapai lebih dari 300-400 spesies. Namun, yang telah lama dikenal dan dipelajari adalah Aloe barbadensis Miller dan Aloe aborescens. ${ }^{2,4}$ Tanaman ini dapat tumbuh subur pada iklim tropik dan daerah curah hujan rendah. ${ }^{4,5}$ Daun Aloe terdiri atas 2 bagian yang berbeda, yaitu: bagian daging yang berlendir dan bagian kulit di tepi sebagai pembungkus. Bagian utama adalah bagian daging, berupa masa jernih, tipis, terasa tawar, yang disebut jeli Aloe vera. ${ }^{4,6}$ Pada beberapa tahun terakhir ini, bagian daging yang berlendir dari daun Aloe vera telah dibuat berbagai preparat, diantaranya berupa jeli Aloe vera yang digunakan sebagai bahan kosmetik dan obat-obatan untuk berbagai penyakit kulit. ${ }^{2,3}$ Ulkus yang sering terjadi dan ditemukan pada mukosa mulut adalah stomatitis aftosa. Peradangan dan rasa nyeri, yang sering menyertai kondisi tersebut di atas sangat mengganggu aktifitas kehidupan individu (termasuk saat makan, minum dan bahkan cara bicara), sehingga hal tersebut mendorong individu yang bersangkutan untuk mencari obat dan atau cara untuk meredakan gejala-gejala tersebut. ${ }^{7,8}$ Bermacammacam preparat, termasuk obat herbal, baik yang digunakan secara sistemik maupun topikal sudah ditemukan cukup efektif untuk meredakan atau menghilangkan rasa nyeri yang setelah digunakan, namun preparat-preparat tersebut ternyata tidak selalu efektif pada semua kasus. ${ }^{7}$ Penelitian ini dilakukan untuk menganalisa konsentrasi terendah dan efektif ekstrak daun Aloe vera dalam mempercepat penyembuhan ulkus mukosa mulut tikus.

\section{METODE}

Daun Aloe vera segar dikumpulkan, dicuci bersih, disterilkan dengan cara mengukus di dalam air mendidih selama 30 menit. Seluruh bagian daun Aloe vera (kulit dan daging) dipotong-potong, dimasukkan ke dalam alat blender. Kemudian dimasukkan ke dalam tabung lyophilized dan disimpan pada $4^{\circ} \mathrm{C}$. Pada 60 tikus jantan umur 3 bulan $(100-120 \mathrm{~g})$ dipilih secara acak, diaplikasi cairan $\mathrm{H}_{2} \mathrm{O}_{2} \quad 10 \%$ pada mukosa labial bibir bawah selama 3 hari, kemudian dimasukkan ke dalam kandang yang telah diberi label kelompok kontrol dan perlakukan. Selama penelitian, semua tikus mendapat perlakuan sama, yaitu selama 12 jam terkena cahaya matahari dan malam tidak diberi cahaya; juga diberi makanan cukup berupa pelet. Penelitian ini juga telah mendapat persetujuan etik dari Komisi Etik. Selama 3 hari selanjutnya, sebelum diterapi, setiap ulkus pada semua tikus diukur diameternya dengan menggunakan kaliper. Setelah itu, pada kelompok kontrol, di area yang sama, dilakukan aplikasi cairan natrium klorida 0,9\% selama $3 \times 5$ menit, dengan interval 90 menit. Sedang pada kelompok perlakuan, dilakukan aplikasi 6,25\%; $12,5 \% ; 25 \%$ ekstrak daun Aloe vera selama 3x5 menit dengan interval 90 menit. Pada hari keempat, 5 tikus dari tiap kelompok dikorbankan. Kemudian, pada kedua kelompok dilakukan aplikasi yang sama pada hari keempat dan kelima. Pada hari keenam 5 tikus dari tiap kelompok dikorbankan. Perlakukan yang sama dilanjutkan pada kedua kelompok sampai hari ketujuh. Pada hari kedelapan, semua tikus yang ada dikorbankan. Jaringan di sekitar ulkus dipotong dan spesimen difiksasi dengan formalin buffer. Spesimen dikirim ke Departemen Patologi untuk dibuat sediaan mikroskopik yang dipotong dengan ketebalan 5 mikron dan dipulas dengan pulasan Hematoxylin dan Eosin. Pengamatan gambaran mikroskopik dilakukan dengan mikroskop cahaya (Olympus, Tokyo), dilakukan skoring secara blind di antara 3 orang peneliti dan dilakukan fotografi pada pembesaran 40x.

\section{HASIL}

Penelitian ini adalah penelitian eksperimental yang dilakukan pada 60 ekor tikus jantan umur 3 bulan (100-120g) dipilih secara acak, dan pada mukosa labial bibir bawah dilakukan aplikasi larutan $\mathrm{H}_{2} \mathrm{O}_{2}$ 10\% 2 kali sehari 2-3 menit selama 3 hari sehingga terbentuk ulkus (Gambar 1).

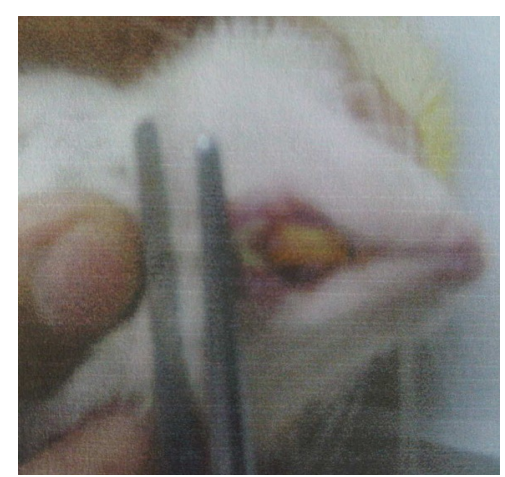

Gambar 1. Ulkus pada mukosa labial bibir bawah 


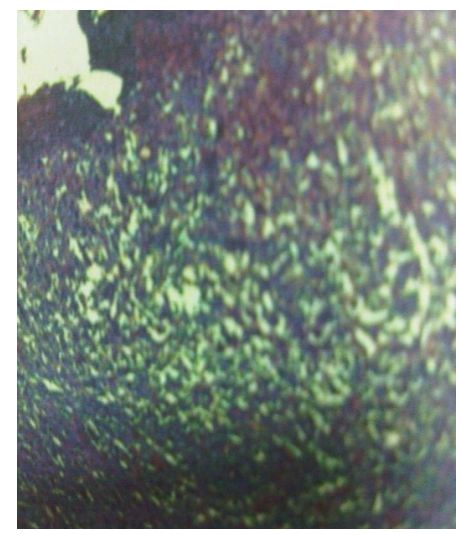

Gambar 2. Gambaran mikroskopis skor radang 4 pada kelompok kontrol

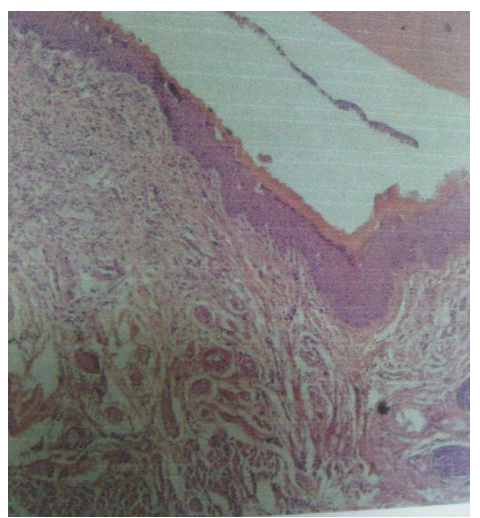

Gambar 3. Gambaran mikroskopis skor radang 1 pada kelompok perlakuan aplikasi ekstrak daun Aloe vera 6,25\% selama3 hari

Gambar 4. Skor radang pada kelompok kontrol yang diaplikasi dengan larutan $\mathrm{NaCl} 0,9 \%$ dan perlakuan yang diaplikasi dengan ekstrak daun Aloe vera 6,25\%; 12,5\% dan 25\% selama 3,5 dan 7 hari

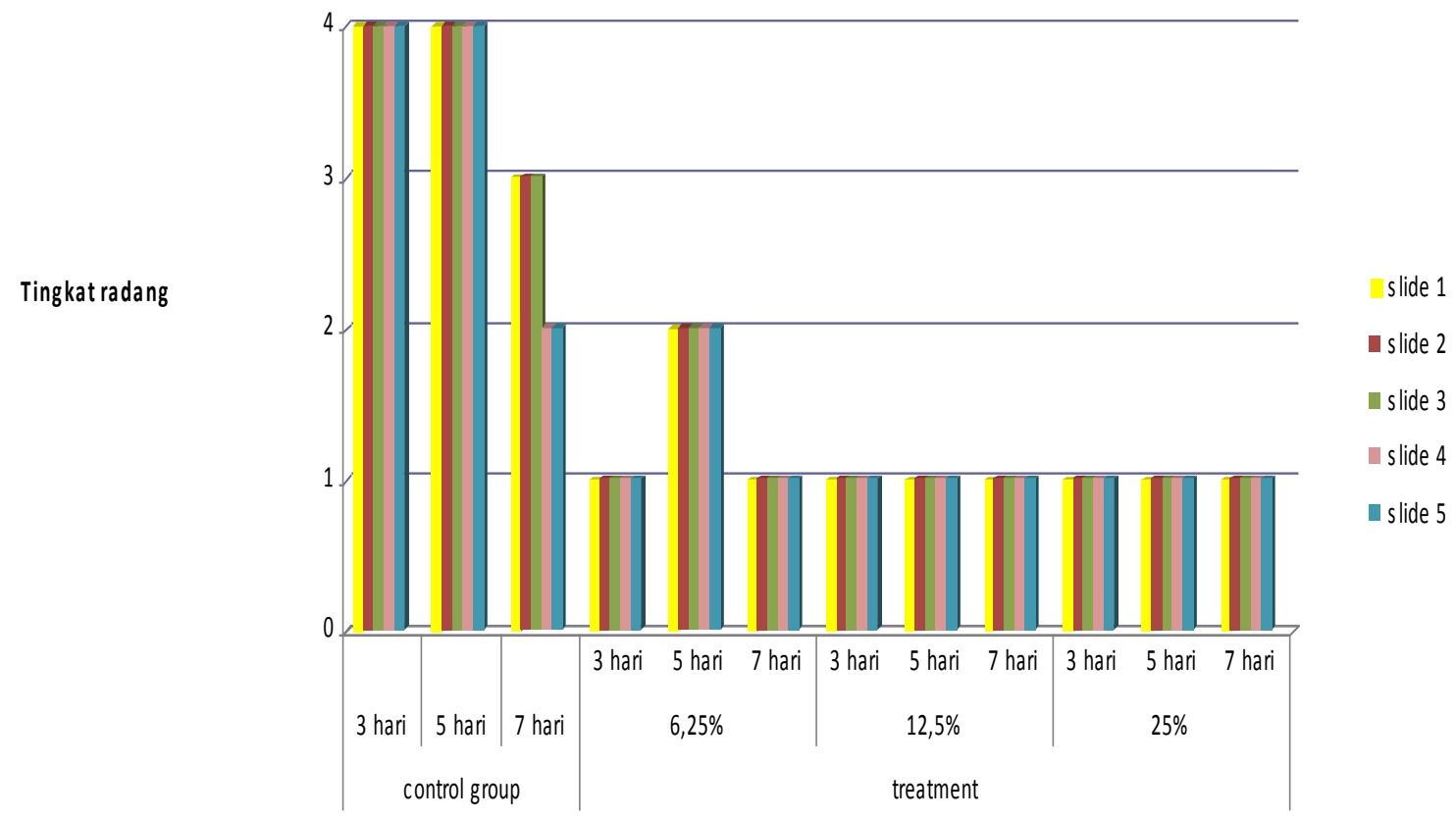

Analisis gambaran mikroskopis pembentukan ulser pada mukosa labial bibir bawah dilakukan dengan menggunakan mikroskop cahaya (Olympus, Tokyo), kemudian dilakukan skoring secara blind di antara para peneliti dan pembuatan fotografi pada pembesaran 40x400. Pada kelompok kontrol, dengan aplikasi $\mathrm{H}_{2} \mathrm{O}_{2} 10 \%$, selama 3 dan 5 hari, analisis gambaran mikroskopik menunjukkan skor radang 4 (Gambar 2). Pada kelompok perlakuan dengan aplikasi ekstrak daun Aloe vera 6,25\%, selama 3 hari dan 7 hari, analisis gambaran mikroskopis menunjukkan skor radang 1 (Gambar 3). Pada gambar 4 tampak bahwa kelompok kontrol hari 3 dan 5 menunjukkan skor radang 4, sedangkan pada kelompok kontrol 7 hari, 3 ekor tikus menunjukkan skor radang 3 dan 2 ekor tikus menunjukkan skor radang 2. Kelompok perlakuan aplikasi daun Aloe vera $6,25 \%$ selama 3 dan 7 hari menunjukkan skor radang 1, sedangkan perlakuan selama 5 hari menunjukkan skor radang 2. Kelompok aplikasi daun Aloe vera 12,5\% selama 3, 5, dan 7 hari menunjukkan skor radang 1 . Kondisi yang sama juga ditemukan pada kelompok aplikasi 25\% selama 3, 5, dan 7 hari yang menunjukkan skor radang 1. Analisa statistik dengan Mann-Whitney $U$ test menunjukkan adanya perbedaan bermakna antara kelompok kontrol dan kelompok perlakukan, pada $p \leq 0,05$.

\section{PEMBAHASAN}

Dalam bidang kedokteran gigi, jeli Aloe vera sudah digunakan sebagai preparat untuk membantu pemulihan atau penyembuhan luka, sebagai antiinfeksi ataupun sebagai antiinflamasi, seperti gingivitis dan periodontitis. $^{1,7,9-11}$ Sebagai antiseptik, Aloe vera 
telah digunakan sebagai bahan irigasi saluran akar dan poket gusi yang pada keadaan normal sulit dibersihkan, juga sebagai obat antijamur pada kondisi sariawan atau luka pada sudut mulut. ${ }^{2,9,10}$ Aloe vera juga telah diproduksi dalam bentuk pasta gigi atau obat kumur; jeli untuk obat luka di kulit; obat semprot topikal untuk infeksi tenggorokan atau luka ekstraksi; jus, sebagai agen detoksifikasi lambung; supplemen dan antioksidan. ${ }^{1,2}$ Salah satu peradangan dan rasa nyeri yang sering ditemukan dalam mukosa mulut adalah stomatitis afthosa (sariawan). Beberapa penyebab timbulnya sariawan, misalnya karena faktor fisik (tergigit, trauma sikat gigi); faktor termis (makanan terlalu panas atau dingin); faktor psikologis. ${ }^{1,2}$ Gambar 4 pada penelitian ini menunjukkan bahwa pada kelompok kontrol tampak bahwa ulkus yang diaplikasi dengan larutan $\mathrm{NaCl}$ $0,9 \%$ selama 3 dan 5 hari menunjukkan gambaran mikroskopis dengan skor 4. Pada aplikasi dengan larutan $\mathrm{NaCl}$ 0,9\% selama 7 hari, menunjukkan sebukan sel radang dengan skor 3 dan 2. Artinya, dapat terjadi penyembuhan spontan pada ulkus tersebut. Hal ini diduga karena adanya proses pemulihan jaringan normal pada mukosa mulut tikus. Hal ini sesuai dengan penulis terdahulu yang menyatakan bahwa pemulihan jaringan ternyata telah dimulai sejak 3-5 hari setelah terjadinya luka jaringan, dimana terjadi proses pembentukan fibroblas dan eliminasi sel-sel radang kronis. Dan setelah setelah hari ke tujuh, tepi luka akan mulai berpaut dan terjadi pembentukan sel epitel yang akan melapisi bagian permukaan luka. ${ }^{12}$ Pada kelompok perlakuan tampak bahwa ulkus yang diaplikasi ekstrak Aloe vera 6,25\% selama 3 dan 7 hari menunjukkan gambaran mikroskopis dengan skor 1 . Sedangkan, aplikasi ekstrak Aloe vera $12,5 \%$ dan $25 \%$ menunjukkan gambaran mikroskopis dengan skor 1 yang berarti dapat membantu penyembuhan luka mukosa mulut tikus. Hal ini diduga karena ekstrak daun Aloe vera mengandung berbagai zat kimia dan berkhasiat sebagai antiinflamasi, antipiretik, antijamur, antioksidan, antiseptik, anti mikroba. Hal ini sesuai dengan penelitian terdahulu yang menyatakan bahwa ekstrak Aloe vera mengandung auksin, gibberrelin, antrakuinon, vitamin A,C,E. ${ }^{1-3}$ Beberapa penelitian lain terdahulu telah membuktikan bahwa Aloe vera berkhasiat sebagai antiinflamasi, antipiretik, antijamur, antioksidan, antiseptik, anti mikroba, serta antivirus. ${ }^{7,9,10}$ Aplikasi ekstrak daun Aloe vera 6,25\% selama 5 hari menunjukkan gambaran mikroskopik dengan skor 2, artinya terdapat penurunan skor radang bila dibandingkan dengan kelompok kontrol 5 hari (skor radang 4). Hal ini diduga karena perilaku tikus-tikus pada kelompok tersebut yang agak sulit ditangani. Walaupun hasilnya tidak seperti pada perlakukan selama 3 dan 7 hari. Hal ini diduga karena ekstrak daun Aloe vera mengandung zat-zat auksin dan gibberllin yang berkhasiat sebagai antiinflamasi dan antiseptik. ${ }^{3}$

\section{SIMPULAN}

Aloe vera berkhasiat sebagai antiinflamasi, antipiretik, antijamur, antioksidan, antiseptik, anti mikroba, serta antivirus. Pada penelitian ini dapat disimpulkan bahwa aplikasi $6,25 \%$ esktrak daun Aloe vera selama 3 hari dapat menyembuhkan ulser mukosa mulut tikus.

\section{DAFTAR PUSTAKA}

1. Bhat G, Kudva P, Dodwad V. Aloe vera: Nature's soothing healer to periodontal disease. J Indian Soc of Period disease. 2011;15:205-9.

2. Feily A, Namazi MR. Aloe vera in dermatology. G Ital Dermatol venerol. 2009;144:85-91.

3. Sarkar D, Dutta A, Das M, Sarkar K, Mandal C, Chatterjee M. Effect of Aloe vera on nitric oxide production by macrophages during inflammation. Indian J Pharmacol. 2005;11:390-5.

4. Reuter J, Jocher A, Stump J, Grossjohann B. Investigation of the anti-inflammatory potential of Aloe vera gel in the ultraviolet erythema test. Skin Pharmacol Physiol. 2008;21:106-10.

5. Grindlay D, Reynolds $T$. The Aloe vera phenomenon: A review of the properties and modern uses of leaf parenchymal gel. J Ethnopharmacol. 1986;16:117-51.

6. Wynn RL. Aloe vera gel: Update for dentistry. Gen Dent. 2005;53:6-9.

7. George D, Bhat SS, Antony B. Comparative evaluation of the antimicrobioal efficacy of aloe vera tooth gel and two popular commercial toothpastes: an in vitro study. Gen Dent. 2009;57:238-41.

8. Langmead L, Makins RJ, Rampton DS. Antiinflammatory effects of Aloe vera gel in human colorectal mucosa in vitro. Aliment Pharmacol Ther. 2004;19:521-7.

9. Babaee N, Zabihi E, Mohseni S, Moghadamnia AA. Evaluation of therapeutic effects of Aloe vera gel on minor recurrent aphthous stomatitis. Dent Res J. 2012;9:381-5.

10. Altenburg A, Zouboulis CC. Current concepts in the treatment of recurrent aphthous stomatitis. Skin Therapy Lett. 2008;13:1-4.

11. Fani M, Kohanteb. Inhibitory activity of Aloe vera gel on some clinically isolated cariogencic and periodontopathic bacteria. J Oral Sci. 2012;54:15-21.

12. Nancy A. Ten cate Oral Histology. 4th ed. Mosby. 2000. 